\title{
HUBUNGAN ANTARA VENTILASI DAN KEPADATAN HUNIAN DENGAN KEJADIAN PENYAKIT ISPA PADA BALITA DI DESA CABEAN KUNTI, KECAMATAN CEPOGO, KABUPATEN BOYOLALI TAHUN 2018
}

\author{
The relationship between ventilation and density in the event of ISPA disease in \\ infants in cabean Kunti village, Cepogo subdistrict, \\ Regency Of Boyolali \\ Year 2018
}

\author{
Sri Sayekti Heni Sunaryanti ${ }^{1}$, Sri Iswahyuni ${ }^{2}$, Herbasuki ${ }^{3}$. \\ STIKES Mamba'ul 'Ulum Surakarta \\ ss.heni.s29@gmail.com
}

\begin{abstract}
ABSTRAK
Latar belakang: Menurut WHO (World Health Organization) pada tahun $2011 \mathrm{di}$ New York jumlah penderita ISPA adalah 48.325 anak dan diperkirakan di negara sedang berkembang berkisar 30-70 kali lebih tinggi dari negara maju dan diduga $20 \%$ dari bayi yang lahir di negara berkembang gagal mencapai usia 5 tahun dan 26-30\% dari kematian anak disebabkan oleh ISPA. Hal ini dapat dilihat dari tingginya angka kesakitan dan kematian akibat ISPA. Kematian akibat penyakit ISPA pada balita mencapai 12,4 juta pada golongan umur 0-1 tahun dan sebanyak 80,3\% kematian ini terjadi di negara berkembang (Kemenkes, 2011).

Di Indonesia pada tahun 2013 prevalensi ISPA secara umum mencapai 25,0\%, hasil Riset Kesehatan Dasar juga menjelaskan bahwa di Indonesia ISPA merupakan penyakit dengan angka kesakitan paling banyak berada pada kelompok umur balita yaitu sebesar $25,8 \%$ pada tahun 2013 dan propinsi Jawa Tengah prevalensi penyakit ISPA secara umum mencapai $26,6 \%$ sedangkan prevalensi ISPA pada balita di propinsi Jawa Tengah sebesar 31,5\% (Balitbankes RI, 2013).

Kondisi sanitasi perumahan yang kurang memenuhi persyaratan tehnis dan hygiene perumahan sehat dapat menimbulkan gangguan kesehatan, misalnya pada penyakit tuberkolosis dan penyakit saluran pernafasan.

Tujuan: Untuk mengetahui hubungan antara ventilasi dan kepadatan hunian dengan kejadian penyakit ISPA didesa Cabean Kunti, Kecamatan Cepogo, Kabupaten Boyolali.

Metode: Jenis penelitian ini adalah penelitian analitik korelasional dengan rancangan Cross Sectional. Populasi sebanyak 162 orang dan sampel diambil dengan purposive sampling sebanyak 100 balita. Data kejadian ISPA diperoleh dengan menggunakan kuesioner dan pengamatan pada ventilasi dan kepadatan hunian pada rumah yang dihuni oleh balita. Analisa data dengan menggunakan analisis chi-Square.

Hasil: Data balita umur terbanyak yang menderita penyakit ISPA dengan batuk > 7 hari sebesar 58 anak (58\%), batuk $<7$ hari sebesar (42) 42\%, keadaan ventilasi
\end{abstract}


yang memenuhi syarat sebesar (72\%), tidak memenuhi syarat (28\%), kepadatan hunian memenuhi standart (54\%), tidak memenuhi standart(46\%), hasil analisa dengan Chi-Square dengan hasil $\mathrm{X}^{2}$ hitung $=2,879$ dengan nilai $p=0,069>.0,05$ berarti tidak ada hubungan antara ventilasi dengan kejadian penyakit ISPA dan kurang signifikan, dengan nilai $\mathrm{X}^{2}$ hitung $=0,896$ dengan nilai $p=0,529>0,05$, tidak ada hubungan antara kepadatan hunian dengan kejadian penyakit ISPA pada balita, dan kurang bermakna kemungkinan ada faktor lain yang mempengaruhi kejadian penyakit ISPA

Simpulan: Tidak ada hubungan antara ventilasi dan kepadatan hunian dengan kejadian penyakit ISPA dan hasil nya kurang signifikan pada balita di Desa Cabean Kunti Kecamatan Cepogo Kabupaten Boyolali

Kata kunci: ventilasi, kepadatan hunian, ISPA.

\begin{abstract}
ABSTRAK
Background: According to WHO (World Health Organization) in 2011 in New York the number of ISPA sufferers is 48,325 children and estimated in the developing country ranges from 30-70 times higher than developed countries and allegedly $20 \%$ of babies born in developing countries fail Reaches the age of 5 years and 26-30\% of child mortality is caused by ISPA. This can be seen from the high numbers of pain and death due to ISPA. The deaths of ISPA in infants reached 12.4 million in the age of 0-1 years and as many as $80.3 \%$ of this death occurred in the developing world (Kemenkes, 2011).

In Indonesia in 2013 the prevalence of ISPA in general is $25.0 \%$, the results of basic health research also explained that in Indonesia ISPA is a disease with the most pain number in the age group of infants is $25.8 \%$ in the year 2013 and Province Jawa TPuff THE prevalence of ispa disease generally reaches $26.6 \%$ while the prevalence of ISPA in infants in Central Java province is $31.5 \%$ (balitbankes RI, 2013).

Housing sanitation conditions that do not meet the requirements of technical and healthy housing hygiene can cause health problems, for example in the disease tuberculosis and Respiratory diseases.

Objectives: to know the relationship between ventilation and density of housing with the incidence of ISPA disease in thevillage Cabean Kunti, District Cepogo, Boyolali District.

Method: This type of research is correlational analytic research with Cross sectional design. Population of 162 people and samples were taken with purposive sampling as many as 100 toddlers. The ISPA event Data is obtained by using questionnaires and observations on ventilation and housing density in households inhabited by toddlers. Analyze the data using the Chi-Square analysis. Result: Data on the most age toddler who suffers from ISPA with cough > 7 days for 58 children (58\%), < 7 days of cough (42) 42\%, eligible ventilation condition (72\%), not eligible (28\%), Occupancy density meets Standart (54\%), not meet standard (46\%), analysis results with Chi-Square with results $X_{\text {count }}^{2}=2.879$ with value $p=0.069>0.05$ means there is no connection between ventilation and
\end{abstract}


Occurrence of ISPA disease and less significant, with a value of $X_{\text {count }}^{2}=0.896$ with a value of $p=0.529>0.05$, there is no relationship between occupancy density with the incidence of ISPA disease in infants, and less Meaning there may be other factors affecting the incidence of ISPA disease

Conclusion: There is no connection between ventilation and density of housing with the incidence of ISPA disease and its results are less significant in thevillage Cabean Kunti, District Cepogo, Boyolali District.

Keywords: ventilation, occupancy density, ISPA.

\section{PENDAHULUAN}

ISPA adalah infeksi akut yang melibatkan organ saluran pernafasan bagian atas dan saluran pernafasan bagian bawah. Infeksi ini disebabkan oleh virus, jamur dan bakteri. ISPA akan menyerang host, apabila ketahanan tubuh (imunologi) menurun. Penyakit ISPA ini paling banyak ditemukan pada anakanak dibawah lima tahun yang merupakan kelompok yang memiliki sistem kekebalan tubuh yang rentan terhadap berbagai penyakit (Danusantoso, 2012).

Sampai saat ini ISPA masih menjadi masalah kesehatan dunia. Menurut WHO (World Health Organization) pada tahun 2011 di New York jumlah penderita ISPA adalah 48.325 anak dan diperkirakan di negara sedang berkembang berkisar 30-70 kali lebih tinggi dari negara maju dan diduga $20 \%$ dari bayi yang lahir di negara berkembang gagal mencapai usia 5 tahun dan 26$30 \%$ dari kematian anak disebabkan oleh ISPA. Hal ini dapat dilihat dari tingginya angka kesakitan dan kematian akibat ISPA. Kematian akibat penyakit ISPA pada balita mencapai 12,4 juta pada golongan umur 0-1 tahun dan sebanyak 80,3\% kematian ini terjadi di negara berkembang (Kemenkes, 2011).

Di Indonesia pada tahun 2013 prevalensi ISPA secara umum mencapai 25,0\%, hasil Riset Kesehatan Dasar juga menjelaskan bahwa di Indonesia ISPA merupakan penyakit dengan angka kesakitan paling banyak berada pada kelompok umur balita yaitu sebesar 25,8\% pada tahun 2013 dan propinsi Jawa Tengah prevalensi penyakit ISPA secara umum mencapai $26,6 \%$ sedangkan prevalensi ISPA pada balita di propinsi Jawa Tengah sebesar 31,5\% (Balitbankes RI, 2013).

Berdasarkan Profil Kesehatan Kabupaten Boyolali tahun 2015 angka kesakitan/ morbiditas yang disebabkan oleh penyakit menular: Infeksi Saluran Pernafasan Akut (ISPA) sebanyak 9.597 balita. Cakupan penemuan penderita pneumonia pada balita masih rendah. Hal ini disebabkan karena belum semua kasus dilaporkan selain belum diterapkannya pendekatan MTBS sehingga dalam pendeteksian dini penderita pneumonia masih kurang sehingga penangganan yang dilakukan oleh petugas sering terlambat atau kurang pasti.

Menurut HL.Blum bahwa derajat kesehatan dipengaruhi oleh 4 (empat) faktor, yaitu : lingkungan, perilaku, pelayanan kesehatan dan keturunan. Faktor lingkungan merupakan faktor yang paling berpengaruh jika dibandingkan dengan faktor-faktor yang lain. Lingkungan yang tidak sehat akan berpengaruh besar terhadap berkembangnya mikroorganisme terutama mikroorganisme patogen yang 
akan berpengaruh terhadap kondisi manusia dalam bentuk gangguan kesehatan atau penyakit.

Rumah yang luas ventilasinya tidak memenuhi syarat akan mempengaruhi kesehatan penghuni rumah, hal ini disebabkan karena proses pertukaran aliran udara dari luar ke dalam rumah tidak lancar sehingga bakteri penyakit ISPA yang ada dalam rumah tidak dapat keluar. Ventilasi juga menyebabkan peningkatan kelembaban ruangan karena terjadinya penguapan cairan dari kulit,oleh karena itu kelembaban ruangan yang tinggi akan menjadi media yang baik untuk perkembangbiakan bakteri penyebab ISPA (Notoatmojo, 2013).

Kondisi sanitasi perumahan yang kurang memenuhi persyaratan tehnis dan hygiene perumahan sehat dapat menimbulkan gangguan kesehatan, misalnya pada penyakit tuberkolosis dan penyakit saluran pernafasan.

Menurut Azwar (1999) : Faktor resiko kejadian ISPA meliputi faktor ekstrinsik dan faktor instrinsik : a. Faktor ekstrinsik adalah kondisi lingkungan fisik rumah (kepadatan penghuni, kondisi ventilasi, kondisi pencahayaan, keberadaan sekat dapur, kondisi lubang asap dapur, kondisi kelembaban). b. Faktor instrinsik adalah umur, jenis kelamin, status gizi, kekebalan tubuh dan status imunisasi.

Berdasarkan data tersebut di atas diduga terdapat hubungan antara ventilasi,dan kepadatan hunian dengan kejadian penyakit Infeksi Saluran Pernafasan Akut ( ISPA) di Desa Cabean Kunti Kecamatan Cepogo Kabupaten Boyolali .

\section{METODE PENELITIAN}

Jenis Penelitian yang digunakan adalah deskriptif analitik. Menggunakan pendekatan cross sectional karena dilaksanakan hanya sekali pada saat/waktu tertentu saja ( Setiadi, 2013). Populasi penderita ISPA sebanyak 162 balita mulai bulan Oktober-Desember 2018 sedang jumlah sampel penelitian sebanyak 100 balita.

Alat dan metode pengumpulan data berupa lembar observasi untuk mengetahui luas ventilasi dan kepadatan hunian dan kejadian ISPA pada balita. Analisis data menggunakan Chi-Square $\left(\mathrm{X}^{2}\right)$.

\section{HASIL DAN PEMBAHASAN}

Tabel 1. Distribusi frekuensi umur balita

\begin{tabular}{ccc}
\hline Umur bulan & f & $\%$ \\
\hline $0-12$ & 25 & 25 \\
$13-24$ & 27 & 27 \\
$25-36$ & 18 & 18 \\
$37-48$ & 19 & 19 \\
$49-60$ & 11 & 11 \\
Total & 100 & 100 \\
\hline
\end{tabular}

Sumber data : primer 
Berdasarkan data pada tabel 1 umur balita 0 -12 (25\%), umur 13-24 (27\%), 25-36 (18\%), umur 37-48 bulan (19\%), umur 49-60 bulan (11\%). Terbanyak umur balita umur antara 0-24 bulan sebanyak 52 anak ( $52 \%$ ).

Tabel 2. Distribusi frekuensi jenis kelamin.

\begin{tabular}{lcc}
\hline Jenis kelamin & $\mathrm{f}$ & $\%$ \\
\hline laki-laki & 40 & 40 \\
perempuan & 60 & 60 \\
Total & 100 & 100 \\
\hline
\end{tabular}

\section{Sumber data primer}

Dari data diatas menunjukkan jenis kelamin balita laki-laki sebesar 40 anak balita(40\%), perempuan 60 anak balita $(60 \%)$. Jenis kelamin balita terbanyak adalah jenis kelamin perempuan.

Tabel 3 : Distribusi frekuensi pendidikan orang tua balita

\begin{tabular}{ccc}
\hline Pendidikan & F & $\%$ \\
\hline SD & 15 & 15 \\
SMP & 23 & 23 \\
SMA & 54 & 54 \\
D 3 & 1 & 1 \\
S1 & 7 & 7 \\
Total & 100 & 100 \\
\hline
\end{tabular}

Sumber data primer

Data tabel 3 pendidikan orang tua balita yang berpendidikan SD sebanyak 15 orang(15\%), SMP 23 orang (23\%), SMA 54 orang (54\%), D3 (1\%), S1 7 orang $(7 \%)$. Terbanyak pendidikan orang tua adalah SLTA dan sederajat.

Tabel 4: Distribusi frekuensi penyakit ISPA pada balita

\begin{tabular}{lrr}
\hline Balita & F & $\%$ \\
\hline Batuk & 81 & 81 \\
tidak & 19 & 19 \\
Total & 100 & 100 \\
\hline
\end{tabular}

Sumber data primer.

Berdasakan data tabel diatas menunjukkan bahwa balita yang menderita ISPA sebesar 81 anak ( $81 \%$ ) balita yang tidak menderita ISPA sebanyak 19 anak $(19 \%)$.

Tabel 5 : Distribusi frekuensi lama batuk

\begin{tabular}{crc}
\hline Batuk & F & $\%$ \\
\hline$<7$ hari & 42 & 42 \\
$>7$ hari & 58 & 58 \\
total & 100 & 100 \\
\hline
\end{tabular}

Sumber data primer 
Data tabel 5 menunjukkan bahwa balita yang, batuk $<7$ hari sebesar 42 anak balita (42\%), >7 hari sebesar 58 anak balita (58\%).

Tabel 6 : Distribusi frekuensi luas ventilasi

\begin{tabular}{lrr}
\hline Ventilasi & F & $\%$ \\
\hline memenuhi syarat & 72 & 72 \\
tidak memenuhi syarat & 28 & 28 \\
Total & 100 & 100 \\
\hline Sumber
\end{tabular}

Sumber data primer

Data tabel 6 luas ventilasi yang memenuhi syarat sebesar 72 rumah ( 72\%) dan yang tidak memenuhi syarat sebesar 28 rumah(28\%).

Tabel 7: Distribusi frekuensi kepadatan hunian

\begin{tabular}{lrr}
\hline Kepadatan hunian & $\mathrm{F}$ & $\%$ \\
\hline sesuai standart & 46 & 46 \\
tidak sesuai standart & 54 & 54 \\
Total & 100 & 100 \\
\hline
\end{tabular}

Sumber data primer.

Data tabel 7 menunjukkan kepadatan hunian yang tidak sesuai standart sebesar 54 rumah $(54 \%)$ dan yang sesuai standart sebesar 46 rumah (46\%).

Kondisi ventilasi dan kepadatan hunian dengan kejadian ISPA yang akan dianalisa dan dihubungkan antara luas ventilasi dan kepadatan hunian dengan kejadian penyakit ISPA adalah sebagai berikut :

a. Hasil uji analisis hubungan antara ventilasi dengan kejadian penyakit ISPA adalah $\mathrm{X}^{2}$ hitung $(2,879)$ dengan $p 0,09>0,05$ berarti tidak ada hubungan yang bermakna antara ventilasi dengan kejadian penyakit ISPA. Hasil analisis dapat dapat dilihat pada tabel dibawah ini :

Chi-Square Tests

\begin{tabular}{|c|c|c|c|c|c|}
\hline & Value & df & $\begin{array}{l}\text { Asy mp. Sig. } \\
\text { (2-sided) }\end{array}$ & $\begin{array}{l}\text { Exact Sig. } \\
\text { (2-sided) }\end{array}$ & $\begin{array}{l}\text { Exact Sig. } \\
\text { (1-sided) }\end{array}$ \\
\hline Pearson Chi-Square & $2.879^{b}$ & 1 & .090 & \multirow{6}{*}{.116} & \multirow{6}{*}{.069} \\
\hline Continuity Correction & 2.164 & 1 & .141 & & \\
\hline Likelihood Ratio & 2.964 & 1 & .085 & & \\
\hline Fisher's Exact Test & & & & & \\
\hline $\begin{array}{l}\text { Linear-by-Linear } \\
\text { Association }\end{array}$ & 2.850 & 1 & .091 & & \\
\hline $\mathrm{N}$ of Valid Cases & 100 & & & & \\
\hline
\end{tabular}

a. Computed only for a $2 \times 2$ table

b. 0 cells $(.0 \%)$ hav e expected count less than 5 . The minimum expected count is 11 . 76.

b. Hasil analisis antara kepadatan hunian kejadian penyakit ISPA dari uji analisis adalah $X^{2}$ hitung $(0,017)$ dengan $p$ 0,896>0,05 dan dapat diartikan tidak ada hubungan yang bermakna antara ventilasi dan kepadatan hunian dengan kejadian penyakit ISPA. Hasil analisis dapat dilihat pada tabel berikut ini : 
Chi-Square Tests

\begin{tabular}{|c|c|c|c|c|c|}
\hline & Value & $\mathrm{df}$ & $\begin{array}{c}\text { Asy mp. Sig. } \\
\text { (2-sided) }\end{array}$ & $\begin{array}{l}\text { Exact Sig. } \\
\text { (2-sided) }\end{array}$ & $\begin{array}{l}\text { Exact Sig. } \\
\text { (1-sided) }\end{array}$ \\
\hline Pearson Chi-Square & $.017^{b}$ & $\overline{1}$ & .896 & \multirow{6}{*}{1.000} & \multirow{6}{*}{.529} \\
\hline Continuity Correctiola & .000 & 1 & 1.000 & & \\
\hline Likelihood Ratio & .017 & 1 & .896 & & \\
\hline Fisher's Exact Test & & & & & \\
\hline $\begin{array}{l}\text { Linear-by-Linear } \\
\text { Association }\end{array}$ & .017 & 1 & .897 & & \\
\hline $\mathrm{N}$ of Valid Cases & 100 & & & & \\
\hline
\end{tabular}

a. Computed only for a $2 \times 2$ table

b. 0 cells $(.0 \%)$ hav e expected count less than 5 . The minimum expected count is 19 . 32.

Hubungan antara ventilasi dan kepadatan hunian dengan kejadian penyakit ISPA, dari hasil analisis menunjukkan bahwa tidak terdapat hubungan yang signifikan antara ventilasi dan kepadatan hunian dengan kejadian penyakit ISPA di Desa Cabean Kunti, Cepogo, Boyolali adalah sebagai berikut :

Hasil analisis dari hasil uji chi- square pada hasil crosstab diatas menunjukkan nilai Chi-Square antara yang memenuhi syarat dengan kondisi ventilasi yang memenuhi syasrat 2,879 dengan probabilitas sebesar 0,09>0,05 sehingga dapat diartikan tidak terdapat hubungan yang signifikan antara ventilasi dengan kejadian penyakit ISPA.

Hasil analisis antara kepadatan hunian dengan kejadian penyakit ISPA dapat dilihat pada crosstab antara hunian yang memenuhi standart dengan yang tidak memenuhi standar adalah sebesar 0,017 denga $\mathrm{p}=0,529>0,05$ dapat diartikan tidak ada hubungan antara kepadatan hunian dengan kejadian penyakit ISPA di Desa Cabean Kunti, Cepogo, Boyolali.

Hasil analisis penelitian ini tidak sesuai dengan penelitian Hartoto Sudibyo (2006) dari hasil penelitiannya bahwa ventilasi ada hubungannya yang bermakna dengan kejadian penyakit TBC Paru di puskesmas Tawangharjo Grobogan, kemungkinan perbedaan musim, lokasi kelengkapan imunisasi, maupun kondisi kesehatan balita, saat ada serangan ISPA, sehingga akan mempengaruhi kejadian penyakit ISPA.

Menurut Notoatmojo (2005), faktor lingkungan, ventilasi salah satu fungsi rumah sebagai tempat tinggal yang sehat bagi setiap manusia dengan keluarga selama masih hidupnya. Menurut DepKes RI, 2000, bahwa rumah yang sehat harus memenuhi syarat antara lain pencahayaan, ventilasi penting untuk pertukaran udara dalam ruangan sehingga temperatur dan kelembaban ruangan dapat terjaga secara optimal, cahaya yang cukup merupakan syarat rumah sehat. Menurut Suharmadi bahwa faktor faktor yang mempengaruhi kejadian ISPA, adalah adanya kuman penyebab, keadaan daya tahan tubuh, kondisi lingkungan, dan menurut ( Lubis, 1995) kondisi rumah terdiri dari kepadatan hunian, ventilasi, pencahayaan dan suhu kelembaban udara. Dan faktor lingkungan lain yang berpengaruh terhadap kejadian ISPA adalah pencemaran lingkungan dan polusi dalam rumah merupakan ancaman kesehatan terutama penyakit ISPA.

Berdasarkan hasil penelitian ini dapat disimpulkan ada faktor lain yang menjadi penyebab terjadinya ISPA pada balita di Desa Cabean Kunti, Cepogo, 
Boyolali. Berdasarkan penyebab ISPA pada balita adalah adanya penyebab, daya tahan tubuh, dan kondisi lingkungan. Faktor lain yang berpengaruh kuat terhadap kejadian ISPA yang belum termasuk variabel yang diteliti oleh peneliti adalah adanya kuman penyebab ISPA dan daya tahan tubuh balita (Notoatmojo,2005; Kemenkes RI,2011).

Peran orang tua dalam pencegahan ISPA pada Balita termasuk dalam peran orang tua dalam perawatan anak. Peran aktif orang tua dalam pencegahan ISPA sangat diperlukan karena yang biasa terkena dampak ISPA adalah anak usia balita dan anak-anak yang kekebalan tubuhnya masih rentan terkena infeksi. Sehingga diperlukan peran orang tua menangani hal ini. Orang tua harus mengetahui tentang dampak negatif dari penyakit ISPA seperti ISPA ringan bisa menjadi Pneumonia yang kronologinya dapat mengakibatkan kematian jika tidak segera ditangani. Pencegahan kejadian ISPA ini tidak terlepas darimperan orang tuayang harus mengetahui cara-cara pencegahan ISPA. ISPA dapat dicegah dengan mengetahui penyakit ISPA, menciptakan lingkungan yang nyaman, dan menghindari faktor pencetus (Andarmoyo,2012)

\section{SIMPULAN DAN SARAN}

\section{Simpulan}

Kondisi ventilasi rumah tidak memenuhi syarat $28 \%$ rumah, dan $72 \%$ memenuhi syarat ventilasi. Kepadatan hunian sebagian besar belum memenuhi standart sebesar 54\%, dan memenuhi standart sebesar $46 \%$, Balita yang yang menderita batuk $<7$ hari sebesar 42 anak $(42 \%)$ dengan batuk disertai panas $>7$ hari sebesar 58 anak balita ( 58\%). Analisis hubungan antara ventilasi dengan kejadian penyakit ISPA. Dengan uji statistik $X^{2}$ hitung $(2,87 \%)$ dengan $\mathrm{p}=0,09>$ 0,05 berarti tidak terdapat hubungan yang signifikant antara ventilasi yang kurang memenuhi syarat dan kurang memenuhi Analisis hubungan antara kepadatan hunian dengan kejadian ISPA terbukti hasil analisis $\mathrm{X}^{2}$ hitung $(0,017)$ dengan $p=$ $0,869>0,05$ berarti tidak ada hubungan antara kepadatan hunian dengan kejadian ISPA di Desa Cabean Kunti, Cepogo, Boyolali

\section{Saran}

Bagi Puskesmas, gar meningkatkan penyuluhan dalam mencegah penyakit penyakit khususnya penyakit ISPA, yang dapat dicegah dengan perbaikan lingkungan, khususnya ventilasi dan kepadatan hunian. Beban kerja tenaga kesehatan kadang tidak sesuai dengan tupoksinya, yang lebih besar administrasi dibandingkan tugas pokok perawat yang seharusnya sesuai program promosi kesehatan, preventiv, dan kuratif, rehabilitasi langsung ke masyarakat, sehingga tugas pokok dan fungsi sebagai perawat kurang maksimal dalam pelayanan, sehingga tenaga kesehatan cenderung menunggu bola pada pasien yang telah menderita sakit. Dengan demikian diharapkan petugas kesehatan terutama perawat dapat memberikan penyuluhan tentang ventilasi dan kepadatan hunian agar kejadian penyakit ISPA dapat dicegah. Bagi Dinas Kesehatan agar lebih meningkatkan program promosi kesehatan agar lebih optimal dengan pelaksanaan program yang dilakukan sesuai dengan planing dan pemberdayaan SDM sesuai 
tupoksi dalam penyuluhan kesehatan kepada masyarakat melalui promosi kesehatan. Penyakit ISPA yang terjadi sering menimpa pada balita sehingga perlunya pendidikan kesehatan bagi orang tua, dan berhak mendapat informasi dalam pencegahan penyakit yang dapat dicegah dengan ventilasi dan kepadatan hunian yang memenuhi syarat dan memenuhi standar. Bagi peneliti selanjutnya, dapat digunakan sebagai referensi dalam pengayaan ilmu sebagai dasar untuk diteliti lebih lanjut.

\section{DAFTAR PUSTAKA}

Andarmoyo, S (2012). Keperawatan Keluarga Konsep Teori, Proses dan Praktik Keperawatan, Jakarta: Graha Ilmu

Anonim.2008. Program Pemberantasan Penyakit ISPA untuk Penanggulangan Pneumonia pada Balita. Diakses : 30 Desember 2018.

http://putraprabu.wordpress.com/2018/30/12/klasifikasi-ispa-pada -balita/

Aswar A., 1999. Pengantar Kesehatan Lingkungan, Jakarta: Mutiara

Balitbangkes RI.2013.Riskesdas Dalam Angka Provinsi Jawa Tengah 2013(vol 7)

Cahya Tri Purnami, Aplikasi SPSS Versi 15, untuk pengelolaan data, 2003.

Danusantoso,H. 2012. Ilmu Penyakit Paru. Edisi 2, Jakarta : EGC

Dep.Kes.RI. 1999. Keputusan Menteri Kesehatan RI No829/Menkes/SK/VII/1999, Tentang Persyaratan Kesehatan Perumahan, Jakarta.

Depkes. RI.,2003. Indikator Indonesia Sehat 2010 dan Pedoman Penetapan Indikator Provinsi Sehat dan Kabupaten/Kota Sehat, Kepmenkes.Nomor 1202/Menkes/SK/VIII/2003, Jakarta

Departemen Kesehatan RI., 2002, Pedoman Pemberantasan Penyakit Infeksi Saluran Pernafasan Akut untuk Penanggulangan Pneumonia pada Balita, Jakarta

Departemen Kesehatan RI., 2000, Bimbingan Ketrampilan dalam Tatalaks penderita ISPA pada anak, Dirjen PPM \& PLP, Depkes. RI., Jakarta.

Dinkes Kabupaten Boyolali, Profil Kesehatan Kabupaten Boyolali, 2015.

Dirjen PPM \& PLP, 2000, Pedoman Pelaksanaan Klinik sanitasi, Departemen Kesehatan RI., Jakarta.

Hartoto,S, 2006. Faktor Faktor Yang Mempengaruhi terjadinya Penyakit ISPA di Grobogan, Universitas Sahid Surakarta. Tidak dipublikasikan.

Imam Ghozali,M,Com,Akt,2002, Statistik Non-Parametrik Teori Aplikasi dengan Program SPSS, Semarang: Badan Penerbit Universitas Diponegoro Semarang.

Ida Bagoes Mantra, Ph.D, 2000, Langkah-langkah enelitian Survei Usula Penelitian Laporan Penelitian, Yogyakarta: Badan Peneliti Fakultas Geografi (BPFG)- UGM.

Notoatmojo, S. 2005. Ilmu Kesehatan Masyarakat, Jakarta : Rineka Cipta.

2012. Metodologi Penelitian Kesehatan Edisi Revisi, Jakarta:

Rineka Cipta.

Nursalam. 2011. Konsep dan Penerapan Metodologi Ilmu Keperawatan. Jakarta : Salemba Medika

Setiadi. 2013. Konsep dan Praktik Penulisan Riset Keperawatan. Yogyakarta : Graha Ilmu 